\title{
Design of a Casting Die in CATIA
}

Lubos Rokyta, MSc., Ondrej Bilek, MSc., PhD.

Department of Production Engineering, Faculty of Technology, Tomas Bata University in Zlín, Nad Stráněmi 4511, 760 05, Zlín, Czech Republic.rokyta.1@seznam.cz, bilek@ft.utb.cz,

Design of a Casting Die made of aluminium alloy components using $C A T I A$ software is described in the article. Computer aided design and construction is necessary for the creation of each part. A lot of tools are implemented in the $C A T I A$ program. These tools are used to design cast parts easily. A few aspects are necessary for this technology- To achieve a quality fine-grained structure without porosity and the oxide inclusions, a possibility to observe the casting, solidification, tempering, easy creation of core and cavity, possibility of rapid design whole mould. This factors influence efficiency of construction, quality of the product and production economy. Use of $C A x$ technologies is necessary to meet the requirements [7]. Simulation in some simulating program occurred before this construction. These programs work on basis of Navier- Stokes law and law of conservation of momentum [4]. Combination of these products influences efficiency, productivity and financial expenses.

Keywords: Casting Die, Construction, CAD, CATIA, Computer Aided Design, Pressure Casting

\section{References}

[1] BLAŠČÍK, F. (1988). aj. Technolologia tvárnenia, zlievarenstva a zvárenia. Bratislava: ALFA, 1988. $680 \mathrm{s.}$

[2] FABIAN, F., SPIŠÁK, E. (2009). Navrhování a výroba s pomocí CA... technologií. Brno: Edice vědecké a odborné literatury, 2009. 398 s., ISBN 978-80-85825-65-7

[3] HATTEL, J. (2005). Fundamentals of Numerical Modelling of Casting Processes. First edition. Kgs. Lyngby : Polyteknisk Forlag, 2005, s. 540, ISBN87-502-0969-8.

[4] NOVÁ, I., HOŠEK, Z., NOVÁKOVÁ, I. (2004). Rozvoj tlakového lití, MM Průmyslové spektrum 5-04, ISSN 1212-2572.

[5] ROWLEY, M. T. (1993). International atlas of casting defects. American Founrymen's society, Inc., 1993, s. 337, ISBN 0-87433-053-X.

[6] VASILKO, K. (2007). Analytická teória trieskového obrábania. 1. st ed. Prešov: FVT, 2007. 338 p. ISBN 97880-8073-759-7.

[7] KUMIČÁKOVÁ, D., ČUBOŇOVÁ, N. (2002). Základy vlastností komplexních CAD systémů. Strojírenská technologie, 2002, vol. VII, no. 1, p. 24-29. ISSN 1211-4162.

[8] GREGER, M., WIDOMSKÁ, M. (2011). Analysis of influence of structure on mechanical properties of AlSiMg aluminium alloy processed by ECAP. Manufacturing Technology, 2011, vol. XI, no. 11, p. 17-22. ISSN 12132489. 